\title{
Kommentar
}

\section{Forsinket diagnose ved tidligere folkesykdom}

Det er lenge siden tuberkulose var en folkesykdom i Norge. Faktisk er det under 100 etniske nordmenn som får aktiv tuberkulose per år, og av disse er langt de fleste eldre personer som er blitt smittet tidlig i livet (1). Når det gjelder innvandrere, er de nesten utelukkende smittet i hjemlandet og har enten aktiv tuberkulose idet de kommer til landet eller latent tuberkulose som aktiviseres etter ankomst (2). I en norsk studie fra 2006 fant man en gjennomsnittlig forsinkelse på 63 dager fra symptomdebut til diagnose (3), noe som er høyt i verdenssammenheng (4).

Lengst forsinkelse fant man blant etnisk norske personer under 29 år som hadde ekstrapulmonal tuberkulose (3), slik som i denne kasuistikken. Man har gjort en utmerket faglig jobb med utredningen, og det er ut fra den lave forekomsten naturlig at tuberkulose kom langt ned på listen av differensialdiagnoser. Den norske virkeligheten er i ferd med å endre seg, og risikoen for at nordmenn kommer i kontakt med smittebærende individer $\emptyset$ ker. Vi må i større grad tenke på tuberkulose som en diagnostisk mulighet og øke vår kunnskap om hvordan man stiller diagnosen.

Et nytt og viktig hjelpemiddel er interferon- $\gamma$ release assays (IGRAs) som Quantiferon-TB Gold (QG) og T-Spot TB. Disse er basert på måling av interferon- $\gamma$-utskilling som respons på stimulering med tuberku- loseantigener hos spesifikke T-lymfocytter. Antigenene (CFP-10 og ESAT 6) er hentet fra RD1-regionen i genomet som er nesten unikt for Mycobacterium tuberculosis, og testene kryssreagerer derfor, i motsetning til Mantoux-testen, nesten ikke med Bacillus Calmette-Guérin (BCG) eller de fleste miljøbakterier (apatogene mykobakterier i jord og vann) (5). Selv om de ikke skiller mellom latent og aktiv tuberkulose, vil en positiv test i en så lavendemisk befolkning som den norske være et varsel om behov for videre utredning. Quantiferon-TB Gold er allerede tilgjengelig ved alle norske universitetssykehus, og flere studier har vist nytten av IGRAs både overfor enkeltpasienter som her, og ved miljøundersøkelser blant helsepersonell (6).

\section{Dag Gundersen Storla}

dags@lds.no

Seksjon for infeksjonsmedisin

Lovisenberg Diakonale Sykehus

Dag Gundersen Storla (f. 1962) er dr.med. og spesialist $\mathrm{i}$ indremedisin og i infeksjonssykdommer. Han er overlege ved Lovisenberg Diakonale Sykehus.

Ingen oppgitte interessekonflikter.

\section{Litteratur}

1. Nasjonalt folkehelseinstitutt. Tuberkulose. Faktaark, oppdatert 2010. www.fhi.no/eway/ default.aspx?pid=233\&trg=MainLeft_5648\& MainArea 5661=5648:0:15,2917:1:0:0:0:0\&MainLef t 5648=5544:50435:1:5647:54:0:0 (25.4.2011).

2. Dahle UR, Eldholm V, Winje BA et al. Impact of immigration on the molecular epidemiology of Mycobacterium tuberculosis in a low-incidence country. Am J Respir Crit Care Med 2007; 176: $930-5$.

3. Farah MG, Rygh JH, Steen TW et al. Patient and health care system delays in the start of tuberculosis treatment in Norway. BMC Infect Dis 2006: 6: 33

4. Storla DG, Yimer S, Bjune GA. A systematic review of delay in the diagnosis and treatment of tuberculosis. BMC Public Health 2008; 8: 15.

5. Lalvani A, Pathan AA, McShane $\mathrm{H}$ et al. Rapid detection of Mycobacterium tuberculosis infection by enumeration of antigen-specific T cells. Am J Respir Crit Care Med 2001; 163: 824-8.

6. Storla DG, Kristiansen I, Oftung F et al. Use of interferon gamma-based assay to diagnose tuberculosis infection in health care workers after short term exposure. BMC Infect Dis 2009; 9: 60.

Mottatt 25.1. 2011, første revisjon innsendt 25.4. 2011, godkjent 30.4. 2011. Medisinsk redaktør Mette Sagsveen. 